\title{
SPORULATION, RADIAL GROWTH AND BIOMASS PRODUCTION OF A. ROBUSTA AND M. THAUMASIUM SUBMITTED TO DIFFERENT METHODS OF PRESERVATION
}

\author{
Marcelo de Andrade Mota ${ }^{1 *}$; Artur Kanadani Campos ${ }^{1}$ Jackson Victor Araújo ${ }^{2}$ \\ ${ }^{1}$ Departamento de Parasitologia, Universidade Federal de Minas Gerais, Belo Horizonte, MG, Brasil; ${ }^{2}$ Departamento de \\ Medicina Veterinária, Universidade Federal de Viçosa, Viçosa, MG, Brasil.
}

Submitted: June 18, 2002; Returned to authors for corrections: October 09, 2002; Approved: April 09, 2003

\begin{abstract}
Biological control is based on the use of microorganisms to combat populations of a specific pathogen. Nematophagous fungi have shown to be promising agents to combat nematode parasites of plants and animals. These organisms produce special structures along the hyphae, named traps, which are responsible for capturing and killing the nematode pre-parasitic stages. The growth of the isolates I31 of Arthrobotrys robusta and NF34a of Monacrosporium thaumasium was studied after submission to four different methods of preservation during eighteen months. The isolates were stored at $4^{\circ} \mathrm{C}$ and cryopreserved with or without addition of cryoprotectants and stored in silica gel. The isolates did not present variation in radial growth when stored at $4^{\circ} \mathrm{C}$ and frozen with or without addition of cryoprotectants. There was no significant difference between the dry mycelial mass of the isolates stored at $4^{\circ} \mathrm{C}$ and those frozen after the addition of cryoprotectants. Storage in silica gel and freezing without cryoprotection interfered negatively in the capacity of the fungi to produce mycelial mass. This characteristic also was observed for sporulation of the two isolates. The behaviour of the isolates when maintained for prolonged periods under laboratory conditions is an important factor for selection of the most efficient method of preservation.
\end{abstract}

Key words: nematophagous fungi, biological control, preservation of microorganisms

\section{INTRODUCTION}

Predatory fungi are recognised as having potential for the biological control of gastrointestinal nematode parasites of domestic animals (5). These fungi produce ring-shaped structures that may be constrictors or non-constrictors, buttons or threedimensional adhesive networks along the length of the hyphae, responsible for immobilisation and penetration of the nematode cuticle (3). Among the Deuteromycetes predatory species known, Arthrobotrys robusta Duddington and Monacrosporium thaumasium Oudermans have been the object of several studies, due to their predatory behaviour towards the larvae of gastrointestinal helminth parasites of bovines $(1,2)$. A. robusta has conidiophores $300 \mu \mathrm{m}$ in length, carrying six spores, measuring $18-27 \mu \mathrm{m}$ in length by $8-12 \mu \mathrm{m}$ in width. Monacrosporium thaumasium shows $250 \mu \mathrm{m}$ in length conidiophores, branched off near the edge, where each extremity carries only one spore measuring $27-49 \mu \mathrm{m}$ in length by $15-23 \mu \mathrm{m}$ in width $(11,12)$. Knowledge of aspects such as radial growth, sporulation capacity and production of biomass is necessary to determine the potential of fungi as efficient agents in programmes of biological control. Maintenance of cultures for prolonged periods may be obtained by means of different methodologies. The choice of a specific protocol for the conservation of a particular fungal species is based on characteristics of the isolates, on the facility of carrying out the method and on the economic costs (7). The objective of this study was to evaluate whether four methods of preservation for prolonged periods interfered in the sporulation capacity, radial growth and mycelial production of fungal predators of the nematodes $A$. robusta and $M$. thaumasium.

\footnotetext{
* Corresponding author. Mailing address: Departamento de Parasitologia. Universidade Federal de Minas Gerais. Caixa Postal 486. 31270-901, Belo Horizonte, MG, Brasil. Fax: (+5531) 3499-2970. E-mail: mmota@icb.ufmg.br
} 


\section{MATERIALS AND METHODS}

Maintenance of Fungal Cultures in Maize Agar Extract at $4^{\circ} \mathrm{C}$

Samples of the isolates I31 of A. robusta and NF34a of $M$. thaumasium were maintained in five culture tubes containing $2 \%$ maize agar extract (MAE) and stored in the dark at $4^{\circ} \mathrm{C}$. The cultures were renewed every six months.

\section{Maintenance of Fungal Cultures in Silica Gel}

Samples of the isolates I31 of A. robusta and NF34a of $M$. thaumasium originating from culture tubes filled with $2 \% \mathrm{MAE}$ at $25^{\circ} \mathrm{C}$ were inoculated into YPSSA sporulation medium $(4 \mathrm{~g}$ yeast extract; $1 \mathrm{~g} \mathrm{~K}_{2} \mathrm{HPO}_{4} ; 0.5 \mathrm{~g} \mathrm{MgSO}{ }_{4} .7 \mathrm{H}_{2} \mathrm{O} ; 20 \mathrm{~g}$ soluble amide, $20 \mathrm{~g}$ agar; 11 distilled water). After seven days, a 5\% solution of sterilised skim milk was added to the surface of each plate on $1 \mathrm{~cm}^{2}$ pieces of filter paper. The pieces of paper thus moistened with a suspension of fungal material were immediately transferred to five flasks containing grains of sterile silica gel. The samples were stored at $4^{\circ} \mathrm{C}$ in the absence of light and humidity. After 18 months the cultures were recuperated by transferring pieces of paper from the flasks with silica to the surface of Petri dishes containing $2 \% \mathrm{MAE}$ and maintaining the dishes at $25^{\circ} \mathrm{C}$.

\section{Maintenance of Fungal Cultures in Liquid Nitrogen $\left(-196^{\circ} \mathrm{C}\right)$}

Samples of the isolates I31 of A. robusta and NF34a of $M$. thaumasium originating from culture tubes filled with $2 \%$ MAE at $25^{\circ} \mathrm{C}$, were transferred to YPSSA medium. After seven days, discs from the periphery of the colony were distributed among 30 cryotubes each containing one of three different treatments: 10 filled with $1.5 \mathrm{ml}$ of $10 \%$ glycerol solution, 10 containing $1.5 \mathrm{ml}$ of $10 \%$ dimethyl sulphoxide (DMSO) solution and 10 containing $1.5 \mathrm{ml}$ of distilled water. The process was carried out in two stages: slow freezing $\left(-1^{\circ} \mathrm{C} / \mathrm{h}\right)$, until the samples reached a temperature de $-20^{\circ} \mathrm{C}$ and then direct immersion in liquid nitrogen and storage at $-196^{\circ} \mathrm{C}$. After 18 months the samples were thawed in a water bath at $37^{\circ} \mathrm{C}$ and sown onto Petri dishes containing $2 \%$ MAE maintained at $25^{\circ} \mathrm{C}$.

\section{Evaluation of Radial Growth of the Isolates I31 and NF34a}

The experiment was carried out on $9 \mathrm{~cm}$ diameter Petri dishes containing $2 \%$ water agar and maintained at $25^{\circ} \mathrm{C}$ during the growth phase. Ten groups were organised with 10 replicates. A disc of culture containing isolate $\mathrm{I} 31$ or NF34a submitted to storage at $4^{\circ} \mathrm{C}$, preservation in silica gel, cryopreservation with DMSO or glycerol or cryopreservation without cryoprotectants was placed in the centre of each dish. The diameter of the colonies was measured on the sixth day of growth with a pachymeter or when one of the cultures had reached the edge of the plates.

\section{Biomass Production}

Production of mycelial mass was carried out in $120 \mathrm{ml}$ Erlenmeyer flasks containing $50 \mathrm{ml}$ Potato Dextrose medium
(PD), in darkness at $25^{\circ} \mathrm{C}$. Ten groups of five replicates each were set up. Dishes of each group were sown with discs of I31 or NF34a isolate cultures that had been submitted to storage at $4^{\circ} \mathrm{C}$, preserved in silica gel, cryopreserved with DMSO or glycerol or cryopreserved without cryoprotectants. The flasks were placed on a shaking table set at $160 \mathrm{rpm}$. After seven days of culturing, the mycelium was separated from the medium using a Buckner funnel coupled to a vacuum pump. The mycelium separated in this process was dried at $105^{\circ} \mathrm{C}$ on plates of predetermined weight for $48 \mathrm{~h}$ to obtain the dry mass obtained under each treatment.

\section{Sporulation of the I31 and NF34a Isolates}

This experiment was carried out using Petri dishes of diameter $9 \mathrm{~cm}$ filled with YPSSA and stored in darkness at $25^{\circ} \mathrm{C}$. Ten groups of 10 replicates each were set up. Discs impregnated with the isolate I31 or NF34a from cultures stored at $4^{\circ} \mathrm{C}$, preserved in silica gel, cryopreserved in liquid $\mathrm{N}_{2}$ with DMSO or glycerol or without cryoprotection were placed on the surface of the agar. After seven days, $10 \mathrm{ml}$ of $0.01 \%$ Tween 20 solution was added to the Petri dishes. Ten readings were made of the solution recovered from the dishes in a Neubauer chamber, from which mean values were calculated and the number of spores for the total initial volume extrapolated.

\section{Statistical Analysis}

The data obtained from the radial growth, mycelium production and sporulation experiments were submitted to ANOVA and compared by Tukey's test using the SAEG statistical package, developed by the Federal University of Viçosa (UFV).

\section{RESULTS}

\section{Evaluation of Radial Growth of the isolates I31 and NF34a}

The I31 and NF34a isolates were able to grow on the surface of $2 \%$ water agar, irrespective of the storage method tested. There was no significant difference at $\mathrm{p} \leq 0.05$ among samples of the isolate NF34a store at $4^{\circ} \mathrm{C}$, frozen with DMSO, glycerol and without cryoprotection and these were the treatments that presented the highest speed of growth. The samples of this isolate conserved in silica gel differed from the means of the other treatments and showed the least amount of growth in this experiment $(\mathrm{p}<0.05)$ (Fig. 1).

Radial growth of the $\mathrm{I} 31$ samples stored at $4^{\circ} \mathrm{C}$, frozen with DMSO or preserved in silica gel did not differ statistically at $\mathrm{p} \leq$ 0.05 . The mean radial growth of the I31 samples frozen with glycerol and those without cryoprotection differed significantly from the other treatments, presenting lower growth in relation to the other methods of preservation to which the isolate was submitted $(\mathrm{p}<0.05)($ Fig. 1). 


\section{Biomass Production}

After seven days of culture, all the samples presented mycelial production in PD medium. There was no significant difference at $\mathrm{p} \leq 0.01$ with regard to the mass produced by the I31 and NF34a isolates, whether stored at $4^{\circ} \mathrm{C}$ or frozen with the addition of DMSO and glycerol. The I31 isolate samples presented greater mycelial production when stored in silica gel or frozen without cryoprotectant, compared to those of NF34a transferred to the same treatments $(\mathrm{p}<0.01)$ (Fig. 2).

\section{Sporulation of the I31 and NF34a isolates}

After 10 days of culture at $25^{\circ} \mathrm{C}$ all samples produced spores on the surface of YPSSA. The samples of isolate I31 presented greatest production of spores in all the storage protocols tested. Comparison of the mean conidia production levels of the isolates revealed that the methods of preservation at $4^{\circ} \mathrm{C}$ and freezing with DMSO did not differ significantly, these being the treatments from which the greatest number of conidia were recovered. Storage of samples in silica gel and freezing without cryoprotection were the methods yielding lowest conidial production $(\mathrm{p}<0.01)($ Table 1$)$.

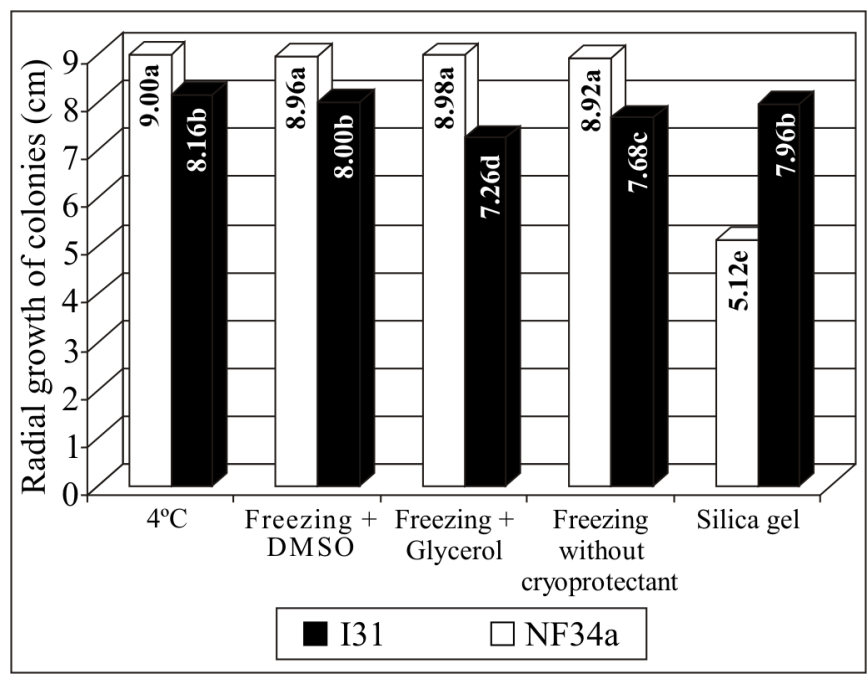

Figure 1. Radial growth $(\mathrm{cm})$ of I31 e NF34a samples submitted to different methods of preservation. Sixth day of culture in $2 \%$ water agar. Means of 10 replicates.

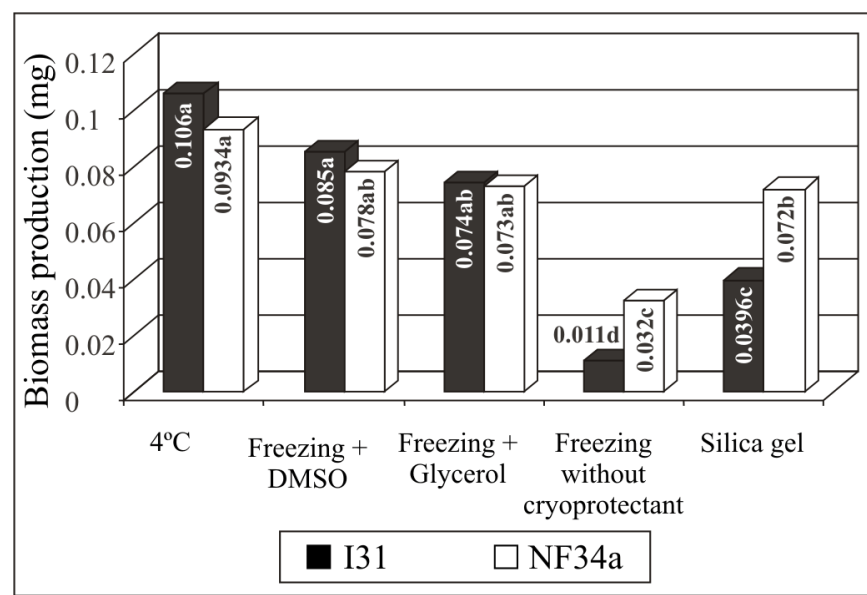

Figure 2. Biomass production (mg) of I31 and NF34a samples submitted to four different methods of preservation after seven days culturing in Potato Dextrose Medium. Mean of five replicates.

\section{DISCUSSION}

The NF34a samples presented greater radial growth on the surface of the dishes than those of isolate I31, except when the former was stored in silica gel. This result may have occurred due of the lower spore production of NF34a, which was reflected in the lower amounts of material preserved in silica gel. The samples from isolates I31 and NF34a did not differ significantly with respect to the production of dry mycelial mass, whether stored at $4^{\circ} \mathrm{C}$, or frozen in liquid $\mathrm{N}_{2}$ after the addition of DMSO or glycerol as cryoprotectants. However storage in silica gel and freezing without cryoprotection both appeared to restrict the capacity of the fungi to germinate and produce mycelial mass. A. robusta, produced more spores than $M$. thaumasium. However, differences were also revealed depending on the treatment to which the samples were submitted. Spore production was the same whether the fungi were stored at $4^{\circ} \mathrm{C}$ or frozen in liquid $\mathrm{N}_{2}$ after the addition of DMSO. As in the previous tests, storage in silica gel and freezing without cryoprotectant both restricted the sporulation rate of the two isolates. Maintenance of the samples at $4^{\circ} \mathrm{C}$ was the treatment that gave the best results based on the parameters tested. This

Table 1. Estimate number of spores x $10^{4}( \pm$ S.D.) produced by I31 and NF34a samples submitted to four different preservation methods. Seventh day of growth in YPSSA. Mean of 10 replicates.

\begin{tabular}{|c|c|c|c|c|c|}
\hline \multirow[t]{2}{*}{ Fungi } & \multicolumn{4}{|c|}{ Preservation Method } & \multirow[b]{2}{*}{ Silica gel } \\
\hline & $4^{\circ} \mathrm{C}$ & $\begin{array}{l}\text { Freezing } \\
+ \text { DMSO }\end{array}$ & $\begin{array}{l}\text { Freezing } \\
+ \text { Glycerol }\end{array}$ & $\begin{array}{l}\text { Freezing without } \\
\text { Cryoprotectant }\end{array}$ & \\
\hline $\mathrm{I} 31$ & $167.20^{\mathrm{A}} \pm 15.78$ & $66.6^{\mathrm{AB}} \pm 5.59$ & $57.1^{\mathrm{B}} \pm 2.10$ & $28^{\mathrm{C}} \pm 6.12$ & $42.7^{C} \pm 3.40$ \\
\hline NF34a & $1.28^{\mathrm{D}} \pm 0,50$ & $0.92^{\mathrm{D}} \pm 0.36$ & $0.76^{\mathrm{D}} \pm 0.23$ & $0.38^{\mathrm{E}} \pm 0.49$ & $0.45^{\mathrm{E}} \pm 0.12$ \\
\hline
\end{tabular}


method would also be the easiest for culture maintenance and causes least fungal stress. Recuperation of the isolates is easy and yields rapid results with respect to the initial characteristics of the samples. However, the appearance of contamination is common and there may be losses to some of the physiological and pathogenic characteristics due to continuous growth, after maintenance for prolonged periods (9). The results presented demonstrate that cryopreservation is an efficient method of maintaining fungi for extended periods. According to the results of the above experiments, the low speed of freezing used in this experiment, together with the high speed of thawed and the use of cryoprotectants were important factors for the recuperation of samples (6). The absence of cryoprotectants could have been responsible for the formation of ice crystals inside the cells, provoking damage to cellular structures during the freezing process (10) and explaining the poorer results obtained for samples submitted to this type of processing. A previous evaluation of the potential of fungal preservation in silica gel revealed that most filamentous fungi tested were able to withstand the stress of processing, even after five years of storage (4), although no attempt was made to assess whether the sample characteristics had been maintained. A more farreaching study demonstrated that ascomycete fungal samples preserved in silica gel could be recuperated even after 25 years (8). This method should not be rejected, since it is easy to implement and some samples remain viable after prolonged periods of storage, although there may be some alterations in the initial characteristics selected. The increased sporulation time of the isolate NF34a in AELA medium before storage in silica gel would increase the quantity of fungal material conserved and in thus the quantity of material recuperated.

\section{RESUMO}

\section{Esporulação, crescimento radial e produção de biomassa dos fungos controladores biológicos $A$. robusta e $M$. Thaumasium submetidos a diferentes métodos de preservação}

O controle biológico é uma técnica baseada no emprego de microorganismos no combate a população de um patógeno específico. Os fungos nematófagos têm demonstrado serem agentes promissores no combate aos parasitos de plantas e de animais. Estes organismos produzem estruturas diferenciadas a partir das hifas, denominadas armadilhas, capazes de capturar e matar os estágios pré-parasitários dos nematóides. Foi avaliado o comportamento dos isolados I31 de Arthrobotrys robusta e NF34a de Monacrosporium thaumasium após terem sido submetidos a quatro métodos de preservação por período de dezoito meses. Os isolados foram armazenados em temperatura de $4^{\circ} \mathrm{C}$, criopreservados com e sem adição de crioprotetores e em sílica-gel. Os isolados I31 e NF34a não apresentaram variação no crescimento radial quando submetidos a armazenamento em temperatura de $4^{\circ} \mathrm{C}$ e congelados com e sem adição de crioprotetores. Não foi evidenciada diferença entre a produção de massa micelial seca dos isolados armazenados em $4^{\circ} \mathrm{C}$ e congelados com adição de crioprotetores. A preservação em sílicagel e o congelamento sem crioproteção demonstraram interferir negativamente na capacidade do fungo em produzir massa micelial. Este comportamento negativo foi evidenciado também na capacidade de esporulação dos isolados. A escolha de um método eficiente de preservação destes microorganismos é uma das formas de se assegurar a capacidade predatória destes isolados após períodos prolongados de manutenção em condições laboratoriais.

Palavras-chave: Fungos nematófagos, controle biológico, preservação de microorganismos

\section{REFERENCES}

1. Araújo, J.V.; Neto, A.P.; Azevedo, M.H.F. Screening parasitic nematodetrapping fungi Arthrobotrys for passage through the gastrointestinal tract of calves. Arq. Bras. Vet. Zoot., 48: 543-552, 1996.

2. Araújo, J.V.; Stephano, M.A.; Sampaio, W.M. Passage of nematodetrapping fungi through the gastrointestinal tract of calves. Vet. Arhiv., 2: 69-78, 1999.

3. Barron, G.L. The nematode-destroying fungi. Canadian Biological Publications, Guelph, 1977, 140p.

4. Gentles, J.C.; Scott, E. The preservation of medically important fungi. Sabouradia, 17: 415-418, 1979.

5. Larsen, M. Biological control of helminths. Int. J. Parasitol., 29: 139-146, 1999.

6. Morris, G.J.; Smith, D.; Coulson, G.E. A comparative study of the morphology of hyphae during freezing with the viability upon thawing of 20 species of fungi. J. Gen. Microbiol., 134: 2897-2906, 1988.

7. Ryan, M.J.; Smith, D.; Jeffries, P. A decision-based key to determine the most appropriate protocol for the preservation of fungi. $W . J$. Microbiol. Biotechnol., 16: 183-186, 2000.

8. Sharma, B.; Smith, D. Recovery of fungi after storage for over a quarter of a century. W. J. Microbiol. Biotechnol., 15: 517-519, 1999.

9. Smith, D.; Onions, A.H.S. The preservation and maintenance of living fungi. CAB International, Wallingford, 1994, 122p.

10. Smith, D.; Thomas, V.E. Cryogenic light microscopy and the development of cooling protocols for the cryopreservation of filamentous fungi. W. J. Microbiol. Biotechnol., 14: 49-57, 1998.

11. Van Oorschot, C.A.N. Taxonomy of the Dactylaria complex. A review of Arthrobotrys and allied genera. St. Mycol., 26: 61-95, 1985.

12. Zhang, K.; Liu, X.; Cao, L.; Ren-Hen, G. A new species of Arthrobotrys from China. Mycol. Res., 100: 527-530, 1996. 